\title{
Identification of compounds adsorbed and deposited on the Ni-Mo catalysts surface of alumina and SBA-15 by DRIFTS, Raman and TPO Analyses before and after Guaiacol hydrodeoxygenation.
}

\section{Rubens W.S. Lima}

Universidade de São Paulo, Escola Politécnica, Departamento de Engenharia Química, Av. Prof. Luciano Gualberto, travessa 3, no. 380, 05508-010, São Paulo, Brasil

Thiago L.R. Hewer

Universidade de São Paulo, Escola Politécnica, Departamento de Engenharia Química, Av. Prof. Luciano Gualberto, travessa 3, no. 380, 05508-010, São Paulo, Brasil

\section{Rita M.B. Alves}

Universidade de São Paulo, Escola Politécnica, Departamento de Engenharia Química, Av. Prof. Luciano Gualberto, travessa 3, no. 380, 05508-010, São Paulo, Brasil

Martin Schmal ( $\square$ schmal@peq.coppe.ufrj.br) Universidade de São Paulo https://orcid.org/0000-0001-6816-523X

\section{Research}

Keywords: Guaiacol Adsorption, hydrodeoxygenation, Ni-Mo, SBA-15, Alumina, DRIFTS, Raman

Posted Date: March 29th, 2021

DOl: https://doi.org/10.21203/rs.3.rs-321528/v1

License: (c) (i) This work is licensed under a Creative Commons Attribution 4.0 International License. Read Full License 


\section{Abstract}

We studied and identified compounds adsorbed or deposited on the catalysts surface of the Ni-Mo supported on alumina and SBA-15, before and after hydrodeoxigenation of a bio-oil model (guaiacol). Marked differences were observed on both catalysts through DRIFTS and Raman spectroscopy showing that the alumina-supported catalyst contains deposits of aromatic and oxygenated organic substances, while the carbon deposits on the SBA-15 as aliphatic simple molecules. TPO analyses confirm that the carbon deposited on the NiMo/SBA-15 catalyst were light polymer types, mainly nanotubes and nano fibers, while on the alumina catalyst the mainly carbon species formed were graphite type and heavier carbons. Post reaction analysis of the catalysts showed coke formation and carbon deposition rate of $1.14 \mathrm{mg}_{\text {coke }} \cdot \mathrm{g}_{\text {cat }}{ }^{-1} \mathrm{~h}^{-1}$ for NiMo/SBA-15 and the deactivation was $44 \%$ higher for the $\mathrm{NiMo} / \mathrm{Al}_{2} \mathrm{O}_{3}$ with $1.65 \mathrm{mg}_{\text {coke }} \cdot \mathrm{g}_{\text {cat }}{ }^{-1} \mathrm{~h}^{-1}$ of carbon deposition rate.

\section{Introduction}

Biomass is an alternative to replace fossil energies, since it is a raw material of low costs and high versatility, which makes it ideal for use as a source of carbon to produce valuable renewable fuels and chemicals using modern pyrolysis techniques [1][2]. It is notable that biomass materials contain high oxygen compounds, and therefore, the deoxygenation through catalytic HDO reactions allows their transformation into hydrocarbon fuels.

However, the main challenge is to develop catalysts able to eliminate as much oxygen as possible without removing the carbon from the fuel and using a minimum amount of hydrogen[3-5]. The hydro deoxygenation (HDO) of bio-oils, lignin and the reaction catalyst stability with time-on-stream is crucial for the industrial utilization of biomass to produce fuels and chemicals

Nickel(Ni) and molybdenum (Mo) or cobalt (Co) and molybdenum sulfide( $\left.\mathrm{MoS}_{2}\right)$ have been employed in $\mathrm{HDO}$ process with different supports, like $\mathrm{SiO}_{2}, \mathrm{ZrO}_{2}, \mathrm{CeO}_{2}, \mathrm{TiO}_{2}, \mathrm{La}_{2} \mathrm{O}_{3}$ oxides, as well as their composites [5]. Lastly, mesoporous silica, such as SBA-15, SBA-16 and MCM-41[6, 7]; zeolites MZ-5, HZSM-5, H-Beta and HY[8-10] and allotropic forms of carbon, for instance active carbon, carbon nanotubes and carbon nanofibers[11, 12] have been used.

The deposition compounds of HDO catalysts is also a key problem, mainly due to severe coke formation [13]. The carbon formation occurs via polymerization and poly-condensation reactions on the acid sites of the support, producing polyaromatic species that may block the active sites of the catalysts[14]. Acidity plays an important role in both selectivity and deactivation, since acid sites can favor specific reaction routes and, thus, generating undesired products, such as polymeric carbon (coke) and heavy organic products[15]. Echeandia et al.[16] proved that there is a proportional ratio between coke production and catalyst total acidity, using palladium supported on HY zeolites in continuous HDO of phenol. Sankaranarayanan et al.[7] studied $\mathrm{Ni}$ and Co catalysts on HZSM-5 zeolite, SBA-15 silica and AlSBA-15 alumino-silicate supports and concluded that nickel, when associated with supports with 
moderate acidity and high surface area, such as HZSM- 5 and Al-SBA-15, have better results for oxygen elimination and hydrogenation of aromatic rings, which makes them ideal catalysts for HDO process. Recently, Hewer et al. [17] studied nickel and molybdenum nanoparticles on silicon aluminum phosphate (SAPO-11) and mesoporous silica (SBA-15), respectively, and compared with $\mathrm{\gamma}-\mathrm{Al}_{2} \mathrm{O}_{3}$ support. These catalysts exhibited excellent catalytic activity for hydrodeoxygenation (HDO) of anisole and the hydrodeoxygenation and hydro-dearomatization reactions are strongly affected by the support nature due to the Brönsted and Lewis acid sites[17].

However, there are different causes that provoke route directions of the hydrogenation process for the formation of HDO and HDA or deoxygenation to aliphatic compounds affecting of the catalyst, which is related to the adsorbed species or intermediate compounds at the surface of the catalysts, which are really the precursors for the selectivity that depend significantly on the supports, in particular, the surface acid sites and dispersions of metallic phases. These species are precursors of carbon formation.

Therefore, we study the nature of the compound deposition occurring on alumina and SBA-15 supports with $\mathrm{Ni}-\mathrm{Mo}$, and identification by the adsorption of intermediate compounds formation during the hydrogenation process of a model compound of bio-oils, analyzing the surface species deposited on the catalysts by comparing before and after reaction. For this purpose, we used spectroscopic analyses, in particular DRIFTS and Raman techniques, complemented by TGA and TPO analyzes.

\section{Experimental}

\subsection{Catalysts preparation}

The SBA-15 support was synthesized following the method described elsewhere [15][18]. In short, $4 \mathrm{~g}$ of the polymer Pluronic P213 (PEO20PPO70PEO20) from BASF was dissolved in $122 \mathrm{~g}$ of HCl 2M solution and kept under stirring for $1 \mathrm{~h}$. Then, $8.6 \mathrm{~g}$ of tetra orthosilicate (Fluka) was added and the solution was continuously stirred for $24 \mathrm{~h}$. The mixture underwent a hydrothermal treatment during $48 \mathrm{~h}$ at $100{ }^{\circ} \mathrm{C}$ in an autoclave, washed thoroughly with deionized water and dried at room temperature. Finally, the polymeric support was calcined at $540^{\circ} \mathrm{C}$ in $\mathrm{N}_{2}$ flow for $2 \mathrm{~h}$ and in air for $4 \mathrm{~h}$. The alumina support ( $\mathrm{Y}$ $\mathrm{Al}_{2} \mathrm{O}_{3}$ ) was acquired from Degussa and calcined at $500{ }^{\circ} \mathrm{C}$ for $20 \mathrm{~h}$ with synthetic air flow and at a rate of $5{ }^{\circ} \mathrm{C} / \mathrm{min}$. Then, nickel and molybdenum were added by wet impregnation in separate. For the required amount of Molybdenum oxide, the salt precursor $\left(\left(\mathrm{NH}_{4}\right)_{6} \mathrm{Mo}_{7} \mathrm{O}_{24} \cdot 4 \mathrm{H}_{2} \mathrm{O}\right)$ was dissolved in deionized water and mixed with the support and the suspension was stirred for $2 \mathrm{~h}$. Afterwards, the mixture was lyophilized for eliminating the residual solvent and calcined at $500^{\circ} \mathrm{C}$ for $2 \mathrm{~h}$ in air flow of $50 \mathrm{ml} \mathrm{min}{ }^{-1}$. Then, the $\mathrm{Ni}\left(\mathrm{NO}_{3}\right)_{2} \cdot 6 \mathrm{H}_{2} \mathrm{O}$ salt (ACROS Organics) was dissolved similarly and impregnated in sequence and calcined under similar conditions.

\subsection{Characterizations}


The textural properties of the catalysts were analyzed by $\mathrm{N}_{2}$ adsorption isotherm, using the Quantacrome volumetric adsorption analyzer (model 100E). The surface area was determined by BET technique and the pore distribution obtained by the BJH method[19,20]. Complete characterization of these materials were reported elsewhere [17].

The metal surface areas and dispersions of the catalysts were determined by $\mathrm{H}_{2}$ chemisorption in an ASAP 2020C chemisorption system (Micrometrics). In a typical analysis, a $120 \mathrm{mg}$ of sample was loaded in the reactor and dried with a He flow for $1 \mathrm{~h}$ at $300^{\circ} \mathrm{C}$ and at rate of $10^{\circ} \mathrm{C} \mathrm{min}{ }^{-1}$. Then, switched to $5 \%$ $\mathrm{H}_{2} /$ Ar flow and reduced for $4 \mathrm{~h}$ at $550^{\circ} \mathrm{C}$ and $10^{\circ} \mathrm{C} \mathrm{min}{ }^{-1}$. After cooling down to $35^{\circ} \mathrm{C}$ and evacuation the total and reversible isotherms and, consequently, the metallic surface areas and dispersions were obtained.

The total acidity of the supports and catalysts was measured by the temperature programmed desorption of $\mathrm{NH} 3$ (NH3-TPD). Approximately $200 \mathrm{mg}$ of the sample was pretreated with a flow of $\mathrm{He}\left(30 \mathrm{ml} \mathrm{min}{ }^{-1}\right)$ at $250{ }^{\circ} \mathrm{C}$ for $1 \mathrm{~h}$ and at $5{ }^{\circ} \mathrm{C} \mathrm{min}{ }^{-1}$. After cooling to room temperature, the gas was replaced by a flow of $4 \% \mathrm{NH}_{3} / \mathrm{He}\left(60 \mathrm{ml} \mathrm{min}^{-1}\right)$ at $150^{\circ} \mathrm{C}$ for $1 \mathrm{~h}$ and cooled to room temperature under pure He flow. Then ammonia desorption took place, raising the temperature at $20^{\circ} \mathrm{C} \mathrm{min}{ }^{-1}$ up to $700{ }^{\circ} \mathrm{C}$. The amount of desorbed ammonia was measured on a quadrupole mass spectrometer (Balzers, PRISMA)

The adsorption on the catalysts surface was studied by in-situ DRIFTS cell using a Nicolet Nexus 870 instrument with a DTGS-TEC detector and a Thermo Spectra-Tech reaction chamber with ZnSe windows. To reduce the sample, $\mathrm{H}_{2}$ was flowed $(40 \mathrm{~mL} / \mathrm{min})$ at $500^{\circ} \mathrm{C}$ for a period of $1 \mathrm{~h}$ and the temperature was decreased to $200{ }^{\circ} \mathrm{C}$ while He was flowed to record a spectrum for use as a background. Guaiacol adsorption involved bubbling $\mathrm{He}(40 \mathrm{~mL} / \mathrm{min})$ through a saturator with guaiacol/n-heptane solution ( $2 \%$ guaiacol, mass \%) for $30 \mathrm{~min}$, followed by a He purge. Spectra were recorded at 200, 250 and $300{ }^{\circ} \mathrm{C}$. The scan resolution was $4 \mathrm{~cm}^{-1}$ and 512 scans were taken.

The Fourier-transform infrared spectroscopy (FTIR) measurements were performed in a Shimadzu IRPrestige-21 spectrometer using $20 \mathrm{mg}$ of the sample pelletized with $\mathrm{KBr}$. Spectra before and after reaction were recorded in a wavelength between $400-4000 \mathrm{~cm}^{-1}$.

The Raman spectrometer, a Renishaw Confocal Raman Microscope model with excitation wavelength of $632 \mathrm{~nm}$, was used for determining carbon deposition after reaction. The crystallite sizes $L_{a}$ of the graphite deposited over the catalysts surface were obtained, according to the Equation 1[21]:

$$
L_{a}(n m)=2,4.10^{-10} \lambda_{\text {laser }}^{4}\left(\frac{I_{D}}{I_{G}}\right)^{-1}
$$

Where, $\lambda_{\text {laser }}$ is the laser wave length used in the Raman experiments, $I_{D}$ and $I_{G}$ are the intensity Raman $\mathrm{D}$ and $\mathrm{G}$ bands of the carbon depositions. 
Thermogravimetric analysis (TGA) and differential thermal analysis (DTA) were performed under a synthetic air flow $\left(100 \mathrm{~mL} \mathrm{~min}^{-1}\right)$, using a Shimadzu DTG-60 equipment. The samples were heated from room temperature up to $900{ }^{\circ} \mathrm{C}$ at $10^{\circ} \mathrm{C} \mathrm{min}^{-1}$.

The carbon deposits formed on the catalysts surface were analyzed by temperature programmed oxidation technique (TPO) in an ASAP 2020C chemisorption system (Micromeritics). In a typical analysis, $120 \mathrm{mg}$ of the sample was dried with $\mathrm{He}$, at $90 \mathrm{~mL} \mathrm{~min}{ }^{-1}$ flow and $300^{\circ} \mathrm{C}$ for 30 minutes. Then, switched to the $\mathrm{O}_{2} / \mathrm{Ar}$ mixture $\left(5 \mathrm{Vol} . \% \mathrm{O}_{2}\right.$ ) flow at $60 \mathrm{~mL} \mathrm{~min}^{-1}$ and heated up to $600{ }^{\circ} \mathrm{C}$ at $10{ }^{\circ} \mathrm{C} \mathrm{min}{ }^{-1}$.

\subsection{Catalytic activity tests}

The catalytic tests were carried out in a fixed bed flow reactor system at $15 \mathrm{kgf.cm}{ }^{-2}$ pressure. The mass around $200 \mathrm{mg}$ was pre-treated in situ with pure $\mathrm{H}_{2}$ (AGA) at $50 \mathrm{~mL} \mathrm{~min}^{-1}$ flow, at $500{ }^{\circ} \mathrm{C}$ for $4 \mathrm{~h}$, and then cooled to the reaction temperature $\left(200,250\right.$ or $\left.300^{\circ} \mathrm{C}\right)$ under hydrogen atmosphere. The feed mixture consisted of $2 \% \mathrm{w} / \mathrm{w}$ Guaiacol (MERCK) in heptane P.A. (Aldrich) pumped at $14.8 \mathrm{~mL} \mathrm{~min}^{-1}$, and carried with $\mathrm{H}_{2}$ flow at $100 \mathrm{~mL} \mathrm{~min}^{-1}$. The reactor input (reactants) and output (products) compounds were maintained in vapor phase, with a steal line heated at $125^{\circ} \mathrm{C}$, until the 6-way valve of the gas chromatograph. The organic compounds were analyzed by gas chromatography in a Shimadzu CG17A equipment, with FID and mass spectrometric detectors, capillary column CP sil 5CB and automatic injection. Conversion, selectivity and reaction rates were determined according to equations 2-4, respectively.

$$
\begin{gathered}
X(\%)=\frac{(\text { Reactant })_{\text {in }}-(\text { Reactant })_{\text {out }}}{\left(\text { Reactant }_{\text {in }}\right.} .100 \\
S_{i}(\%)=\frac{C_{i}}{\sum C_{i}}=\frac{\text { Product }_{i} f_{i} / \text { Product }_{i} f_{i}}{\left.\sum \text { Product }_{i} / \text { Product }_{i}\right)} \cdot 100 \\
r_{\text {cat }}=F_{0} \cdot \frac{X}{100} \cdot \frac{M_{G U A}}{m_{\text {cat }}}
\end{gathered}
$$


Where, $\mathrm{F}_{0}$ is the molar flow rate of Guaiacol, $\mathrm{M}_{\mathrm{GUA}}$ is the Guaiacol molecular weight and $\mathrm{m}_{\text {cat }}$, the mass of the catalyst.

\section{Results And Discussion}

Table 1 presents the surface areas of the supports $\mathrm{Al}_{2} \mathrm{O}_{3}$ and $\mathrm{SBA}-15,279 \mathrm{~m}^{2} \mathrm{~g}^{-1}$ and $630 \mathrm{~m}^{2} \mathrm{~g}^{-1}$, respectively. The SBA-15 presents a total pore volume of $1.17 \mathrm{~cm}^{3} \mathrm{~g}^{-1}$ and an average pore diameter of 7 $\mathrm{nm}$. The surface area and the pore volume of the catalyst NiMo/SBA-15 decreased to $332 \mathrm{~m}^{2} \mathrm{~g}^{-1}$ and $0.68 \mathrm{~cm}^{3} \mathrm{~g}^{-1}$, respectively. The surface area of $\mathrm{NiMoAl}_{2} \mathrm{O}_{3}$ catalyst also decreased, as shown in Table 1 .

Table 1

Textural properties of the supports and Ni-Mo catalysts.

\begin{tabular}{|c|c|c|c|c|}
\hline Catalyst & $\begin{array}{l}\text { Specific surface area }\left(m^{2} g-\right. \\
\text { 1) }\end{array}$ & $\begin{array}{l}\text { Pore } \\
\text { Volume } \\
\left(\mathrm{cm}^{3} \mathrm{~g}^{-1}\right)\end{array}$ & $\begin{array}{l}\text { Pore } \\
\text { diameter } \\
(\mathrm{nm})\end{array}$ & $\begin{array}{l}\text { Metal Acidity } \\
\text { Dispersion } \mathrm{NH}_{3}- \\
\text { TPD } \\
(\%)\left(\mu \mathrm{mol} \mathrm{g}{ }^{-1}\right)\end{array}$ \\
\hline SBA-15 & 630 & 1.17 & 7 & \\
\hline $\mathrm{Al} 2 \mathrm{O} 3$ & 279 & 0.95 & 7.8 & 731 \\
\hline $\begin{array}{l}\text { NiMo/SBA-15 } \\
\text { fresh }\end{array}$ & 332 & 0.68 & 7.4 & 1.8470 \\
\hline $\begin{array}{l}\text { NiMo/SBA-15 } \\
\text { spent }\end{array}$ & 261 & 0.59 & 6.5 & \\
\hline $\mathrm{NiMo} / \mathrm{Al}_{2} \mathrm{O}_{3}$ fresh & 233 & 0.78 & 7.9 & 0.454 \\
\hline $\mathrm{NiMo} / \mathrm{Al}_{2} \mathrm{O}_{3}$ spent & 157 & 0.64 & 9.7 & \\
\hline
\end{tabular}

The total acidity of the supports and catalysts was measured by Temperature Programmed Desorption of $\mathrm{NH}_{3}\left(\mathrm{NH}_{3}\right.$-TPD). Table 1 showed that SBA15 has a total acidity of $470 \mu \mathrm{mol} \mathrm{g}^{-1}$, while the alumina of 548 $\mu \mathrm{mol} \mathrm{g}{ }^{-1}$. The excess of acidity $\left(>890 \mu \mathrm{mol} \mathrm{g}^{-1}\right)$ causes an increase of polymerization products, resulting in the formation of coke at the catalyst surface [22].

\section{IR spectra of Guaiacol adsorption}

The IR spectra of Guaiacol adsorbed on NiMo-SBA15 and NiMo-Al $\mathrm{O}_{3}$ are compared in Fig. 1. In the high frequency region, bands at 2966, 2935 and $2873 \mathrm{~cm}^{-1}$, corresponding to $\mathrm{v}\left(\mathrm{CH}_{\text {ring }}\right)$ and $\mathrm{v}\left(\mathrm{CH}_{3}\right)$ of

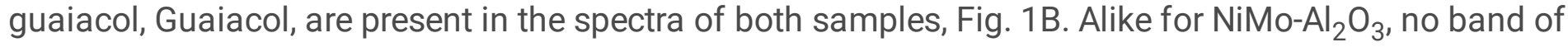
free $\mathrm{OH}$ groups of guaiacol at $3555 \mathrm{~cm}^{-1}$ was detected in the NiMo-SBA15 spectrum. The guaiacol adsorption spectra on $\mathrm{NiMo}-\mathrm{Al}_{2} \mathrm{O}_{3}$, in low frequency region, exhibits characteristic bands of aromatic ring vibration $\left[\mathrm{v}\left(\mathrm{CC}_{\text {ring }}\right)\right]$ at $1581 \mathrm{~cm}^{-1}$ and broad band centered at $1463 \mathrm{~cm}^{-1}$ related to $\delta\left(\mathrm{CH}_{3}\right)$ vibration and 
with $\delta(\mathrm{OH})$ contribution. The poor resolved band at $1355 \mathrm{~cm}^{-1}$, corresponding to $\delta(\mathrm{OH})$ vibration, close to that observed for free gGuaiacol,Guaiacol, is present in its spectra [23]. For the NiMo-SBA15, the guaiacol adsorption spectrum at low frequencies was very different from that observed for $\mathrm{NiMo}-\mathrm{Al}_{2} \mathrm{O}_{3}$. The band characteristic of the $\mathrm{v}\left(\mathrm{CC}_{\text {ring }}\right)$ vibration shifts to $1599 \mathrm{~cm}^{-1}$ and the band at $1492 \mathrm{~cm}^{-1}$ of the $\mathrm{v}\left(\mathrm{CC}_{\text {ring }}\right)$ is clearly observed. The bands of $\delta\left(\mathrm{CH}_{3}\right)$ vibration, a triplet between $1463-1442 \mathrm{~cm}^{-1}$, are present in the NiMo-SBA15 spectra. The band at 1355 of $\delta(\mathrm{OH})$ vibration does not appear in the NiMo-SBA15 spectra, which indicates the absence of free phenol on its surface.

After guaiacol adsorption, the chamber was cleaned with He flow during 30 minutes and temperature increased up to $300^{\circ} \mathrm{C}$, Fig. $2 \mathrm{~A}$. In the high frequency region, guaiacol was still adsorbed on the $\mathrm{SiO}_{2}$ surface and it is possible to observe the low intensity bands in the range $3000-2800 \mathrm{~cm}^{-1}$. In fact, the guaiacol adsorption leads to a decrease of free $\mathrm{Si}-\mathrm{OH}$ groups, as evidenced in the negative band at 3750 $\mathrm{cm}^{-1}$, and this behavior indicates the silanol groups were perturbed by the interaction with guaiacol through its aromatic ring[24, 25].

For the NiMo-SBA15 after evacuation and with increasing temperature from 200 to $300^{\circ} \mathrm{C}$, the bands at 1587 and $1492 \mathrm{~cm}^{-1}$, corresponding to aromatic ring vibrations $\mathrm{v}(\mathrm{CC})$ were still present, however, the band $1454 \mathrm{~cm}^{-1}$ is more sensitive and disappeared at $300^{\circ} \mathrm{C}$. The broad multicomponent envelope at 1353 to $1267 \mathrm{~cm}^{-1}$ is characteristic of the stretching modes of $\mathrm{C}-\mathrm{OH}$ and $\mathrm{C}-\mathrm{OCH}$. The IR spectra

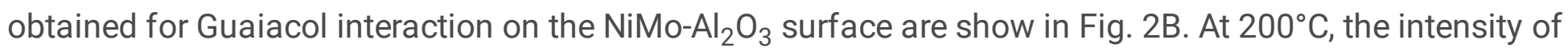
the $1463 \mathrm{~cm}^{-1}$ band decreases and the bands at $1581 \mathrm{~cm}^{-1}$ and $1359 \mathrm{~cm}^{-1}$ are still the same. However, with increasing temperature to 250 and $300^{\circ} \mathrm{C}$, the bands attributed to the vibrational modes $\mathrm{v}\left(\mathrm{C}=\mathrm{C}_{\text {ring }}\right)$ 1581 and $1355 \mathrm{~cm}^{-1}$ of $\delta(\mathrm{OH})$ decreased. The opposite was observed for the new band at $1496 \mathrm{~cm}^{-1}$, and the band at $1454 \mathrm{~cm}^{-1}$, assigned to $\mathrm{v}\left(\mathrm{C}=\mathrm{C}_{\text {ring }}\right)$ and $\mathrm{CH}_{3}$ vibrational modes, respectively. In the same way, but less intense, new bands can be observed in the $1200-1300 \mathrm{~cm}^{-1}$ region, which are attributed to the $\mathrm{v}(\mathrm{CO})$ vibration.

\section{hydrodeoxygenation of Guaiacol}

The catalytic test results of conversion and reaction rates at $200,250,300^{\circ} \mathrm{C}$ are shown in Table 2 and Fig. 3. 
Table 2

Reaction conditions, conversions, product distribution and HDO and HDA conversions

\begin{tabular}{|lllllll|}
\hline Catalyst & NiMo/SBA-15 & \multicolumn{5}{l|}{${\mathrm{NiMo} / \mathrm{Al}_{2} \mathrm{O}_{3}}$} \\
\hline Space velocityWSHV $\left(\mathrm{h}^{-1}\right)$ & 1.57 & & & 1.24 & \\
\hline Temperature $\left({ }^{\circ} \mathrm{C}\right)$ & 200 & 250 & 300 & 200 & 250 & 300 \\
\hline Conversion $(\%)$ & 3.7 & 74.5 & 84.7 & 5.1 & 45.0 & 72.6 \\
\hline HDO (\%) & 92.1 & 74.3 & 66.5 & 37.9 & 31.5 & 30.8 \\
\hline HDA (\%) & 84.2 & 48.7 & 35.3 & 23.1 & 12.3 & 2.7 \\
\hline Selectivity (\%) & & & & & & \\
\hline Benzene & 16.7 & 8.6 & 1.3 & 3.3 & 1.1 & 0.3 \\
\hline Cyclohexane & 29.1 & 13.9 & 11.0 & 6.8 & 3.3 & 0.4 \\
\hline Cyclohexene & 38.5 & 26.2 & 19.5 & 12.9 & 7.9 & 1.9 \\
\hline Phenol & 10.5 & 17.4 & 34.2 & 16.3 & 24.8 & 41.3 \\
\hline o-Cresol & 0.0 & 18.4 & 8.0 & 7.7 & 8.5 & 11.3 \\
\hline Monoxigenates & 5.3 & 15.5 & 20.2 & 5.8 & 4.9 & 3.8 \\
\hline Dioxigenates & 0.0 & 0.0 & 2.3 & 47.2 & 49.4 & 41.0 \\
\hline
\end{tabular}

The conversion of guaiacol increased with temperature. At $300^{\circ} \mathrm{C}$, the conversions were $85 \%$ for NiMo on SBA-15 and $73 \%$ for alumina catalysts, respectively. These results are in good agreement with the literature for $\mathrm{HDO}$ reactions [27, 28-31]. Figure 3B displays the reaction rate with increasing temperature and both catalysts. Note that the influence of the support was significant, indicating that the NiMo/SBA15 was higher than $\mathrm{NiMo} / \mathrm{Al}_{2} \mathrm{O}_{3}$.

\section{Selectivity and products distribution}

The selectivity and products are presented in Table 2 and Fig. 4 and show significant influence of the support. In fact, comparing both catalysts, three main aspects may be analyzed: the selectivity of nonoxygenated compounds is higher on NiMo/SBA-15 than on $\mathrm{NiMo} / \mathrm{Al}_{2} \mathrm{O}_{3}$ for all temperatures; the selectivity to phenol is higher on $\mathrm{NiMo} / \mathrm{Al}_{2} \mathrm{O}_{3}$ for all temperatures; and the deoxygenated compounds (catechol, methyl Guaiacol and derivatives) are formed mostly on $\mathrm{NiMo} / \mathrm{Al}_{2} \mathrm{O}_{3}$ for all temperatures. The selectivity to phenol is higher on $\mathrm{NiMo} / \mathrm{Al}_{2} \mathrm{O}_{3}$ for all temperatures. SBA-15 support presents basically Si$\mathrm{OH}$ groups, which act as Lewis acid sites. The SBA- 15 has higher ability for direct demethoxylation of Guaiacol resulting in phenol, while the alumina support has had more ability for demethylation, forming catechol, which is transformed to phenol through hydrogenolysis [5, 29-32]. 
It depends on presence of the metallic oxide sites $\mathrm{Ni}$ and $\mathrm{Mo}$ on the surface. The first for activation of hydrogen and the second for adsorption of oxygenated compounds, due to the oxo facility [33]. Therefore, the molybdenum on the surface of SBA-15 favored the demethyloxylation of the guaiacol molecule, forming phenol.

In fact, the alumina support presents greater amount and higher acid forces than the SBA-15, thus directing the reaction to a different route. The strong Lewis sites adsorb guaiacol molecules through the oxygen of the methoxyl groups, and consequently, favors the rupture of methyl and adsorption on the surface[34,35]. Therefore, the main product is catechol and its methyl derivatives.

In fact, phenol can also be formed through hydrogenolysis of catechol due to the Mo sites on the surface of the supports, which explains the higher amount of the phenol formed on the alumina catalyst compared to the SBA-15 catalyst, in accordance to [30]. Indeed, the energy needed for total elimination of oxygen for both catalysts is different. On silica, it needs the rupture of the ether bindings $\mathrm{C}\left(\mathrm{sp}^{2}\right)-\mathrm{OCH}_{3}$ $(356 \mathrm{~kJ} / \mathrm{mol})$ and the phenolic bonding $\mathrm{C}\left(\mathrm{sp}^{2}\right) \neg \mathrm{OH}(414 \mathrm{~kJ} / \mathrm{mol})$, while for the alumina catalyst, occurs the rupture of the methyl group $\mathrm{C}\left(\mathrm{sp}^{3}\right)-\mathrm{OC}\left(\mathrm{sp}^{2}\right)(247 \mathrm{~kJ} / \mathrm{mol})$, followed by two phenolic bonds. Therefore, the SBA-15 catalyst has greater facility to generate non-oxygenated compounds or with less oxygen atoms, following a reaction energetically more favorable than on the alumina catalyst. Results evidence that the selectivity depends on the support but significantly on the product distribution.

\section{Analyses after reaction}

\section{IR analyses}

Figure 5 shows the FTIR spectra of the fresh NiMo/SBA- 15 and NiMo/ $/ \mathrm{Al}_{2} \mathrm{O}_{3}$ catalysts, respectively. The $\mathrm{NiMo} / \mathrm{SBA}-15$ catalyst presented bands relative to $\mathrm{Si}-\mathrm{O}-\mathrm{Si}$ and $\mathrm{Si}-\mathrm{OH}$ bonds of the silica support and bindings relative to $\mathrm{Mo}=0$ and Mo-O-Mo of the molybdenum oxide. The bands $800-812 \mathrm{~cm}^{-1}$ are relative to the stretched symmetric Si-O-Si bridged structure of the mesoporous silica; the band at 950 $\mathrm{cm}^{-1}$ refers to the stretched silanol band of $\mathrm{Si}-\mathrm{OH}$ on the surface due to the defects of the structure; the band at $1090 \mathrm{~cm}^{-1}$ corresponds to the asymmetric bridged Si-O-Si bonding; and finally the band 3440 $\mathrm{cm}^{-1}$ to the silanol groups of Si-OH and hydroxyls of the water adsorbed on the catalyst surface [36, 37].The band $1640 \mathrm{~cm}^{-1}$ is attributed to the adsorbed water [45]. In this spectrum it was not possible to detect the Ni-O bond, which occurs between 400 and $500 \mathrm{~cm}^{1}$, as well as the bands relative to the bonding of $\mathrm{Mo}=\mathrm{O}$ of the $\mathrm{MoO}_{3}$, which would appear between 800 a $1000 \mathrm{~cm}^{-1}$, probably because the silica bands overlap the nickel and molybdenum oxide band[38, 39].The Mo-0-Mo bonding, that occurs in this range [40],shows similar behavior. Finally, the small band at $704 \mathrm{~cm}^{-1}$ can be attributed to the stretching symmetric band of Ni-Mo-O present on the mixed oxide $\mathrm{NiMoO}_{4}[41]$.

After reaction it is noteworthy to observe significant modification in the IR spectrum of the silica catalyst. New bands appeared at 1390 and $1470 \mathrm{~cm}^{-1}$, which are assigned to the rotation vibration and folding of 
$\mathrm{C}-\mathrm{H}$ bonds of methyl groups [42]. The formation of $-\mathrm{CH}_{3}$ groups at the catalysts surface during the reaction is closely related to the deactivation due to the carbon deposition on its surface[43]. The band intensity is low, in agreement with the literature, since on silica supports the carbonaceous species formation is low [44].

The infrared spectra of the $\mathrm{NiMo} / \mathrm{Al}_{2} \mathrm{O}_{3}$ catalyst before and after reaction are shown in Fig. 5B. A broad band was observed between 600 and $1000 \mathrm{~cm}^{-1}$, which can be assigned to the unfolding $0-A l-0$ bonding and the stretching bond of $\mathrm{Al}-\mathrm{O}$ [45-47]. As observed previously the $\mathrm{Mo}=\mathrm{O}$ and Mo-O-Mo bands appear in the same interval and are less sensitive at 625 and $750-850 \mathrm{~cm}^{-1}$. The first band was not observed on the SBA-15 support, which evidenced the Mo-Al-O bond interacting with the alumina support, due to the presence of the $\mathrm{Al}_{2}\left(\mathrm{MoO}_{4}\right)_{3}$, as identified by XRD [48]. The bands between 750 and $850 \mathrm{~cm}^{-1}$ are assigned to the stretching of the $\mathrm{Mo}=0$ terminal bond (perpendicular to the $\mathrm{MoO}_{3}$ laminar structure) and the stretching bond of Mo-O-Mo [49]. The band $1630 \mathrm{~cm}^{-1}$ evidenced the $\mathrm{H}-\mathrm{O}-\mathrm{H}$ bonding of water at 3450 $\mathrm{cm}^{-1}$ to the vibration of hydroxyls on the surface (Al-OH) and of water in the lattice.

After reaction the spectrum of the alumina supported catalyst (Fig. 5B) presented significant differences in the range 1000 and $1600 \mathrm{~cm}^{-1}$, with appearance of new bands at 1014, 1102, $1260 \mathrm{e} 1500 \mathrm{~cm}^{-1}$. Indeed, the bands at $1014 \mathrm{~cm}^{-1}, 1102 \mathrm{~cm}^{-1}, 1260 \mathrm{~cm}^{-1}$, and $1500 \mathrm{~cm}^{-1}$ are attributed to the unfolding C$\mathrm{H}$ band bonded to the aromatic rings, the stretching $\mathrm{C}-\mathrm{O}$ (alcohol/phenolic), stretching of $\mathrm{C}-\mathrm{O}$ (ether) and stretching of aromatic $\mathrm{C}=\mathrm{C}$ bands, respectively, according to Silverstein [42]. Note, that all these bonds evidenced the aromatic compounds adsorbed on the surface of the alumina catalyst. Indeed, there are reports indicating that alumina support favors the formation of heavy aromatic compounds due to the strong adsorption of Guaiacol on its surface. This kind of molecules could favor the formation of methylsubstituted derivatives, like $\left(-\mathrm{CH}_{3}\right)$, hydroxyl $(-\mathrm{OH})$ or other aromatic compounds on the catalysts surface in agreement with the literature $[3,34,43,50]$. As consequence, these organic compounds promote coke deposition on the catalyst and blocking surface active sites. The $-\mathrm{CH}_{3}$ band is lighter for the NiMo/SBA15 catalyst, suggesting easier desorption, probably due to the substituted reactions with the heavier adsorbed products on SBA-15. In fact, aromatic bands were not observed on SBA-15, which adsorbed preferentially methyl groups, suggesting higher stability concerning the deactivation process when compared to the alumina support.

\section{Raman spectroscopy analyses}

The Raman spectroscopy of the catalysts was performed for identifying the structures of the synthesized materials between 300 to $1100 \mathrm{~cm}^{-1}$, and the carbon structure formed on the catalysts surface after the hydro deoxygenation of the guaiacol in the wavelength range of $1100-1800 \mathrm{~cm}^{-1}$, Fig. 6 . For NiMo/SBA15 fresh catalysts, there are stretching bonds of Si-O-Si at $453 \mathrm{~cm}^{-1}$ and stretching of siloxane rings of SBA-15 support at $484 \mathrm{~cm}^{-1}$. 
The band at $389 \mathrm{~cm}^{-1}$ is assigned to the bending bonding of $0-\mathrm{Mo}-\mathrm{O}$ of the $\mathrm{MoO}_{3}$ and the band at 723 $\mathrm{cm}^{-1}$ is assigned to the symmetric stretching bonds of $\mathrm{Ni}-\mathrm{Mo}-\mathrm{O}$ of the $\mathrm{NiMoO}_{4}$. Asymmetric stretching bonds of O-Mo-O of the $\mathrm{MoO}_{3}$ occurred at 829 and $900 \mathrm{~cm}^{-1}$. Finally, the band located at $958 \mathrm{~cm}^{-1}$ is assigned to the stretching bonds of $\mathrm{Mo}=\mathrm{O}$ on the $\mathrm{NiMoO}_{4}$ and $\mathrm{Mo}-\mathrm{O}$ on the polymeric $\mathrm{MoO}_{\mathrm{x}}$ species. The presence of these bindings confirms the presence of $\mathrm{MoO}_{3}$ e $\mathrm{NiMoO}_{4}$ species, as observed and identified by XRD results. Moreover, the identified band at $958 \mathrm{~cm}^{-1}$ is attributed to the $\mathrm{NiMoO}_{4}$ species, which indicates that this oxide is a well-defined crystalline structure, in agreement with the literature[51-53].

The Raman spectrum of the NiMo/SBA-15after reaction between 1000 and $1800 \mathrm{~cm}^{-1}$ indicates the broad carbonaceous species present on the catalyst surface, from graphite to amorphous carbons. In fact, the band at $1324 \mathrm{~cm}^{-1}$ is assigned as D1 carbon structures that correspond to unordered and poorly organized carbon [54]. On the other hand, at $1589 \mathrm{~cm}^{-1}$ is the $\mathrm{G}$ band, indicating the well-organized structure like graphite, carbon nanotubes or carbon fibers, according to SHANMUGAN et al.[55]. Besides, the band at $1265 \mathrm{~cm}^{-1}$ shows the D4 band and the bands $1485 \mathrm{~cm}^{-1}$ and $1552 \mathrm{~cm}^{-1}$, identified as D3 are assigned to disordered graphite matrices and amorphous carbons, respectively [54, 56]. It seems that on the silica support the carbon structure is less organized (D1 band) and exhibits defects (D4 band), and therefore, less organized structures like graphite ( $G$ band). These results corroborate with the TPO analyses, which demonstrated the deposition of light carbons deposited on NiMo/SBA-15. It can also be attributed to defects of polymeric structures, like carbon nanotubes of fibers. The organization degree of the carbon structure formed at catalysts surface was measured from the ratio between $D$ and $G$ band intensities. For NiMo/SBA-15, this ratio is 2.05 suggesting higher disordered carbon structure formed on the catalysts surface during the HDO reaction. The crystallite size $L_{a}$ of the carbon deposits was calculated according to Eq. 1. For NiMo/SBA-15spent catalysts it was $18.8 \mathrm{~nm}$, Table 3. This value is greater than the mean pore sizes of the SBA-15 support, around $8.77 \mathrm{~nm}$, as observed by TEM analyses [17], which suggests that most carbon was deposited on the surface and blocked most of the pores of the support. In fact, it decreased the surface area of the NiMo/SBA-15 after reaction, and provoked high deactivation due to the carbon deposition.

The Raman results of the fresh $\mathrm{NiMo} / \mathrm{Al}_{2} \mathrm{O}_{3}$ catalyst present similar vibration bands as observed for SBA15 and $\mathrm{MoO}_{3}$ was the predominant phase, while the $\mathrm{NiMoO}_{4}$ appeared with lower intensity, not observed through XRD. The well-defined band of the polymeric $\mathrm{MoO}_{3}$ indicates higher degree of crystallization of the molybdenum oxide phase, which corroborates with the great crystallite sizes calculated from the Xray diffraction pattern.

From the Raman spectrum of the $\mathrm{NiMo} / \mathrm{Al}_{2} \mathrm{O}_{3}$ after reaction, it is possible to observe the bands at 1271 $\mathrm{cm}^{-1}$ (D4), $1343 \mathrm{~cm}^{-1}$ (D1), $1462 \mathrm{~cm}^{-1}$ (D3) and $1593 \mathrm{~cm}^{-1}$ (G)assigned to the different carbon allotropes. The spectrum shows well defined D1 and G bands, and shoulders, as indicated in bands D4 and $D 3$. The calculated ratio between $I_{D} / I_{G}$ was 0.99 , indicating that the carbon formed deposits with similar proportion of graphitic allotrope and disordered carbon, Table 3. However, the presence of D3 and 
D4 bands denotes the amorphous and disordered carbon on the carbon deposits. The crystallite size of the carbon deposits formed on $\mathrm{NiMo} / \mathrm{Al}_{2} \mathrm{O}_{3}$ was $38.5 \mathrm{~nm}$, which is 2.5 higher compared to NiMo/SBA-15. Probably, the deactivation was more pronounced since the sizes are much bigger than the pore sizes of alumina support, around $7.9 \mathrm{~nm}$.

Table 3

Properties of carbon deposits formed on the catalysts surface after the hydro deoxygenation of guaiacol.

\begin{tabular}{|lll|}
\hline Catalysts & Ratio $\mathrm{I}_{\mathbf{D}} / \mathrm{I}_{\mathbf{G}}$ & Carbon crystallite size $(\mathrm{nm})$ \\
\hline $\mathrm{NiMo} / \mathrm{SBA}-15$ & 2,05 & 18,8 \\
$\mathrm{NiMo} / \mathrm{Al}_{2} \mathrm{O}_{3}$ & 0,99 & 38,5 \\
\hline
\end{tabular}

Thermogravimetric and Thermodifferential analyses

Thermogravimetric analyses of the spent catalysts were performed with air flow and increasing temperature at $10^{\circ} \mathrm{Cmin}^{-1}$ up to $900^{\circ} \mathrm{C}$. The TGA and DTA results are presented in Table 4, that shows water elimination of $11.1 \%$ and physisorbed water $[57,58]$. At higher temperature the weight loss was 1.8 $\%$ due to the decomposition of silanol and siloxane groups, which suggests high stability of the support at high temperatures $[58,59]$.The spent NiMo/SBA-15catalysts showed less water elimination $(5.6 \%)$. However, the exothermal peak at $305^{\circ} \mathrm{C}$ and the endothermic peaks at 431 and $536^{\circ} \mathrm{C}$ indicate coke burn. Then, comparing the mass loss of the fresh and spent catalysts, there is a loss of $3.1 \%$, and the carbon deposition rate was $1,14 \mathrm{mg}_{\text {coke }} g_{\text {cat }}{ }^{-1} \mathrm{~h}^{-1}$. 
Table 4

Results of the weight loss for the spent and fresh catalysts from thermogravimetric curves.

\begin{tabular}{|c|c|c|c|c|}
\hline Catalyst & $\begin{array}{l}\text { Initial Weight } \\
\text { (mg) }\end{array}$ & $\begin{array}{l}\text { Temperature } \\
\text { Range } \\
\left({ }^{\circ} \mathrm{C}\right)\end{array}$ & $\begin{array}{l}\text { Weight } \\
\text { loss } \\
(\%)\end{array}$ & $\begin{array}{l}\text { Coke formation } \\
\left(\mathrm{mg}_{\text {coke }} \mathrm{g}_{\text {cat }}{ }^{-1} \mathrm{~h}^{-}\right. \\
\text {1) }\end{array}$ \\
\hline \multirow[t]{2}{*}{ NiMo/SBA-15 fresh } & 2.5 & $25-300$ & 11,1 & \multirow[t]{2}{*}{-} \\
\hline & & $300-900$ & 1,8 & \\
\hline \multirow{2}{*}{$\begin{array}{l}\text { NiMo/SBA-15spent } \\
(28 \mathrm{~h})\end{array}$} & 2.5 & $25-250$ & 5,6 & \multirow[t]{2}{*}{1.14} \\
\hline & & $250-900$ & 4,9 & \\
\hline \multirow[t]{3}{*}{$\mathrm{NiMo} / \mathrm{Al}_{2} \mathrm{O}_{3}$ fresh } & 11.2 & $25-150$ & 9,3 & \multirow[t]{3}{*}{-} \\
\hline & & $150-840$ & 6,5 & \\
\hline & & $840-900$ & 6,9 & \\
\hline \multirow{3}{*}{$\begin{array}{l}\mathrm{NiMo} / \mathrm{Al}_{2} \mathrm{O}_{3} \text { spent ( } 36 \\
\text { h) }\end{array}$} & 11.2 & $25-250$ & 2,4 & \multirow[t]{3}{*}{1.65} \\
\hline & & $250-840$ & 12,1 & \\
\hline & & $840-900$ & 6,5 & \\
\hline
\end{tabular}

The carbon deposition rate was $1.65 \mathrm{mg}_{\text {coke }} \mathrm{g}_{\mathrm{cat}}{ }^{-1} \mathrm{~h}^{-1}$ for $\mathrm{NiMo} / \mathrm{Al}_{2} \mathrm{O}_{3}$. In addition, the sublimation of $\mathrm{MoO}_{3}$ occurred at $836^{\circ} \mathrm{C}$, corresponding to a mass loss of $6.5 \%$ as observed for the non-used sample. Comparing to Olcese's et al. work [60], the carbon deposition rate was $3.2 \mathrm{mg}_{\text {coke }} \mathrm{g}_{\text {cat }}{ }^{-1} \mathrm{~h}^{-1}$ after HDO reaction of guaiacol on $10 \% \mathrm{Fe} / \mathrm{SiO}_{2}$ catalyst.

\section{TPO analyses}

Temperature programmed oxidation was employed for catalysts before and after reaction, using a mixture of $5 \% \mathrm{O}_{2} / \mathrm{He}$ and exit gases were analyzed by mass spectroscopy, as shown in Fig. 7.

The results showed the mass signals of $\mathrm{CO}, \mathrm{CO}_{2}$ and $\mathrm{H}_{2}$ before and after reaction. For the fresh $\mathrm{NiMo} / \mathrm{SBA}-15$ the profiles didn't show any important signal of $\mathrm{CO}$ or $\mathrm{CO}_{2}$, indicating that all organic products present were eliminated during the calcination. But, the $\mathrm{H}_{2}$ profile presented two broad peaks at 250 and $560^{\circ} \mathrm{C}$, which are attributed to elimination of hydroxyls groups present at the silica surface [61].

After reaction we observe three broad peaks from room temperature up to $600^{\circ} \mathrm{C}$, with maximum at 371 ${ }^{\circ} \mathrm{C}$ for $\mathrm{H}_{2}$, at $400{ }^{\circ} \mathrm{C}$ for $\mathrm{CO}$ and at $276^{\circ} \mathrm{C}$ for $\mathrm{CO}_{2}$, which indicates decomposition of the coke formed at the surface during the $\mathrm{HDO}$ reaction.

Considering $\mathrm{CO}_{2}$ as reference, due to the total combustion of carbon, we suggest that most coke deposited on the NiMo/SBA-15 are of polymeric types, such as carbon nanotubes, carbon nanofibers with 
low weight, because the production of $\mathrm{CO}_{2}$ occurred at low temperature $\left(276^{\circ} \mathrm{C}\right)$. According to Lee et al. [62], this behavior could be assigned to the burning of light and well-organized carbonaceous species. However, the broad peak indicates also the presence of different carbon materials of polymerization products, as also observed by Kim et al. [63] for ethanol reforming on Ni/SBA-15 e NiMo/SBA-15 catalysts. In fact, nickel promoted the polymerization of ethylene, while molybdenum the partial oxidation, resulting in $\mathrm{CO}$ adsorption, which was deposited as coke around metallic particles, like small donuts circling the metallic active sites. In fact, Omoregbe et al. and Wang et al. [64,65] proved that graphitic carbon on metallic sites burns at temperatures above $550{ }^{\circ} \mathrm{C}$, while polymeric carbon burnt at lower temperatures. These authors observed the influence of the support with higher Lewis sites concentrations tend to improve the adsorption of acids, and carbon dioxide, which can reduce the carbon deposition.

On the other hand, the fresh $\mathrm{NiMo} / \mathrm{Al}_{2} \mathrm{O}_{3}$ showed higher $\mathrm{H}_{2}$ formation than the NiMo/SBA-15 sample, which are assigned to the higher hydroxyl content at the alumina surface [66]. The low $\mathrm{CO}$ and $\mathrm{CO}_{2}$ formation at lower temperature are organic impurities adsorbed on the alumina support. However, the spent catalyst displayed high amounts of $\mathrm{de}_{2}, \mathrm{CO}$ e $\mathrm{CO}_{2}$ formation, certainly due to the carbon deposition at the surface. For all signals it is possible to see two peaks, the first one at $50^{\circ} \mathrm{C}$ extended to $250^{\circ} \mathrm{C}$ and the second one from 250 to $600^{\circ} \mathrm{C}$, with maximum around 415 and $450^{\circ} \mathrm{C}$. These results suggest two different carbon species deposited, one less organized and with low weight for lower temperatures and the other one well-structured and higher weight burning at higher temperatures. The first coke burnt up to $250^{\circ} \mathrm{C}$ are assigned to aromatic organic compounds with low polymerization degree and strongly adsorbed at the surface. These results reinforce the FTIR results indicating aromatic bonds of type $\mathrm{C}=\mathrm{C}, \mathrm{C}-\mathrm{H}$ and $\mathrm{C}-\mathrm{O}$ adsorbed on the surface of the materials, which agrees with Olcese et al. [60], for the $\mathrm{HDO}$ on a $\mathrm{Fe} / \mathrm{SiO}_{2}$ catalyst. Indeed, these carbons are quite different from those deposited on SBA-15 materials. The carbon deposits formed on $\mathrm{NiMo} / \mathrm{Al}_{2} \mathrm{O}_{3}$ are predominantly graphite carbons. These carbons allotropes have well organized and dense structures when compared to the carbon nanotubes and nanofibers observed for the NiMo/SBA-15 catalyst $[16,55,62]$.

Paivi et al 67] studied the Hydro deoxygenation (HDO) of bio-oils, lignin and the reaction catalyst stability with time-on-stream for understanding the industrial utilization of biomass in HDO to produce fuels and chemicals. Our results showed that more oxygenated feedstock, as well as presence of certain catalyst poisons influence the HDO performance and the results evidence carbon allotropes.

\section{Conclusions}

Comparing the selectivity of both catalysts, three main aspects may be analyzed: the selectivity of nonoxygenated compounds is higher on NiMo/SBA-15 than on $\mathrm{NiMo} / \mathrm{Al}_{2} \mathrm{O}_{3}$; the selectivity to phenol is higher on $\mathrm{NiMo} / \mathrm{Al}_{2} \mathrm{O}_{3}$ and the deoxygenated compounds (catechol, methyl guaiacol and derivatives). The SBA15 support presents basically Si-OH groups, which act as Lewis acid sites and has higher ability for direct demethoxylation of guaiacol resulting in phenol. 
After reaction it is noteworthy to observe significant modification in the IR spectrum of the silica catalyst. New bands appeared at 1390 and $1470 \mathrm{~cm}^{-1}$, which are assigned to the rotation vibration and folding of $\mathrm{C}-\mathrm{H}$ bonds of methyl groups. The formation of $\mathrm{CH}_{3}$ groups at the catalysts surface during the reaction is closely related to the deactivation due to the carbon deposition on its surface. After reaction the spectrum of the alumina supported catalyst presented significant differences in the range 1000 and 1600 $\mathrm{cm}^{-1}$, with appearance of new bands which are attributed to the unfolding $\mathrm{C}-\mathrm{H}$ band bonded to the aromatic rings.

After reaction, the infrared spectroscopy showed that the alumina-supported catalyst contained deposits of aromatic and oxygenated organic substances, while the carbon deposited on SBA-15 materials are mainly the aliphatic type of simpler molecules. TPO analyses showed that the carbons deposited on the $\mathrm{NiMo/SBA}-15$ catalyst were light polymer types, mainly nanotubes and nanofibers, while on the alumina catalyst it was of graphite type and heavier carbons were formed. This data was confirmed by Raman spectroscopy, displaying disorganized and defective carbonaceous structures on NiMo/SBA-15. On the other hand, in the alumina, the graphitic carbon was found in a greater proportion than in the previous one, besides structures of amorphous carbon and graphite defective. TGA analyses presented the amount of coke deposition after HDO, 1.14 and $1.65 \mathrm{mg}_{\text {coke }} \mathrm{g}_{\mathrm{cat}}{ }^{-1} \mathrm{~h}^{-1}$ on SBA-15 and alumina, respectively.

\section{List Of Abbreviations}

DRIFTS: Diffuse Reflectance Infrared Transmission Spectroscopy

Raman: Raman spectroscopy

TPO: Temperature Programmed Oxidation

HDO: Hydrodeoxigenation

TPD: Temperature Programmed Desorption

FTIR: Fourier Transform Infrared spectroscopy

TGA and DTA: Thermogravimetric and Thermodifferential Analyses

\section{Declarations}

Ethics approval and consent to participate: Not applicable.

Consent to publication: Not applicable.

Availability of data and materials: The datasets used and/or analyzed during the current study are available from the corresponding author as requested. 
Competing interests: The authors declare that they have no competing interests.

Funding: This work was supported by the Coordenação de Aperfeiçoamento de Pessoal de Nível Superior

- Brasil (CAPES) - Finance Code 001 and by Conselho Nacional de Desenvolvimento Científico e Tecnológico CNPq 1

Authors' contributions: Rubens W.S. Lima performed the experiments and wrote the first draft of the manuscript under the constant technical guidance of Thiago L.R. Hewer. Rita M.B.Alves revised the manuscript and Martin Schmal, provided the research idea along with discussion and revision of the final text.

Acknowledgements: The authors would like to thank Dr. Rodrigo Bonfim from NUCAT-UFRJ.for help with catalyst characterization. Thanks to University of S.Paulo, LAPCat and FAPESP for supporting the research program

\section{References}

1. Harrabin R (2012) UN climate talks extend Kyoto Protocol, promise compensation, BBC NEWS Sci. https://www.bbc.com/news/science-environment-20653018 (accessed November 1, (2018)

2. Espinosa P, Mezouar S, Paris Agreement Enters into Force - Celebration and Reality Check, United Nation Clim. Chang. Opin (2016) https://unfccc.int/index.php/news/paris-agreement-enters-intoforce-celebration-and-reality-check (accessed October 25, 2018)

3. Asadieraghi M, Wan Daud WMA, Abbas HF (2014) Model compound approach to design process and select catalysts for in-situ bio-oil upgrading. Renew Sustain Energy Rev 36:286-303. https://doi.org/10.1016/j.rser.2014.04.050

4. Bu Q, Lei H, Zacher AH, Wang L, Ren S, Liang J, Wei Y, Liu Y, Tang J, Zhang Q, Ruan R (2012) A review of catalytic hydrodeoxygenation of lignin-derived phenols from biomass pyrolysis. Bioresour Technol 124:470-477. https://doi.org/10.1016/j.biortech.2012.08.089

5. Saidi M, Samimi F, Karimipourfard D, Nimmanwudipong T, Gates BC, Rahimpour MR (2014) Upgrading of lignin-derived bio-oils by catalytic hydrodeoxygenation. Energy Environ Sci 7:103-129. https://doi.org/10.1039/C3EE43081B

6. Loricera CV, Pawelec B, Infantes-Molina A, Álvarez-Galván MC, Huirache-Acuña R, Nava R, Fierro JLG (2011) Hydrogenolysis of anisole over mesoporous sulfided CoMoW/SBA-15(16) catalysts, Catal. Today 172:103-110. https://doi.org/10.1016/j.cattod.2011.02.037

7. Sankaranarayanan TM, Berenguer A, Ochoa-Hernández C, Moreno I, Jana P, Coronado JM, Serrano DP, Pizarro P (2015) Hydrodeoxygenation of anisole as bio-oil model compound over supported $\mathrm{Ni}$ and Co catalysts: Effect of metal and support properties. Catal Today 243:163-172. https://doi.org/10.1016/j.cattod.2014.09.004

8. Zhao C, Lercher JA (2012) Selective Hydrodeoxygenation of Lignin-Derived Phenolic Monomers and Dimers to Cycloalkanes on Pd/C and HZSM-5 Catalysts, ChemCatChem. 4 64-68. 
https://doi.org/10.1002/cctc.201100273

9. Ausavasukhi A, Huang Y, To AT, Sooknoi T, Resasco DE (2012) Hydrodeoxygenation of m-cresol over gallium-modified beta zeolite catalysts. J Catal 290:90-100. https://doi.org/10.1016/j.jcat.2012.03.003

10. Hong D-Y, Miller SJ, Agrawal PK, Jones CW (2010) Hydrodeoxygenation and coupling of aqueous phenolics over bifunctional zeolite-supported metal catalysts. Chem Commun 46:1038-1040. https://doi.org/10.1039/B918209H

11. Santos JL, Alda-Onggar M, Fedorov V, Peurla M, Eränen K, Mäki-Arvela P, Centeno M, Murzin DY (2018) Hydrodeoxygenation of vanillin over carbon supported metal catalysts. Appl Catal A Gen 561:137-149. https://doi.org/10.1016/j.apcata.2018.05.010

12. Dongil AB, Pastor-Pérez L, Sepúlveda-Escribano A, García R, Escalona N (2016) Hydrodeoxygenation of guaiacol: Tuning the selectivity to cyclohexene by introducing Ni nanoparticles inside carbon nanotubes. Fuel 172:65-69. https://doi.org/10.1016/j.fuel.2016.01.002

13. Centeno A, Laurent E, Delmon B (1995) Influence of the Support of CoMo Sulfide Catalysts and of the Addition of Potassium and Platinum on the Catalytic Performances for the Hydrodeoxygenation of Carbonyl, Carboxyl, and Guaiacol-Type Molecules. J Catal 154:288-298. https://doi.org/10.1006/jcat.1995.1170

14. Furimsky E, Massoth FE (1999) Deactivation of hydroprocessing catalysts. Catal Today 52:381-495. https://doi.org/10.1016/S0920-5861(99)00096-6

15. Cordero-Lanzac T, Palos R, Hita I, Arandes JM, Rodríguez-Mirasol J, Cordero T, Bilbao J, Castaño P (2018) Revealing the pathways of catalyst deactivation by coke during the hydrodeoxygenation of raw bio-oil. Appl Catal B Environ 239:513-524. https://doi.org/10.1016/j.apcatb.2018.07.073

16. Echeandia S, Pawelec B, Barrio VL, Arias PL, Cambra JF, Loricera CV, Fierro JLG (2014) Enhancement of phenol hydrodeoxygenation over Pd catalysts supported on mixed HY zeolite and Al203. An approach to O-removal from bio-oils. Fuel 117:1061-1073. https://doi.org/10.1016/j.fuel.2013.10.011

17. Hewer TLR, Souza AGF, Roseno KTC, Moreira PF, Bonfim R, Alves RMB, Schmal M (2018) Influence of acid sites on the hydrodeoxygenation of anisole with metal supported on SBA-15 and SAPO-11. Renew Energy 119:615-624. https://doi.org/10.1016/j.renene.2017.12.044

18. Matos JR, Mercuri LP, Kruk M, Jaroniec M (2001) Toward the synthesis of extra-large-pore MCM-41 analogues. Chem Mater 13:1726-1731. https://doi.org/10.1021/cm000964p

19. Brunauer S, Emmett PH, Teller E (1938) Adsorption of Gases in Multimolecular Layers. J Am Chem Soc 60:309-319. https://doi.org/10.1021/ja01269a023

20. Barrett EP, Joyner LG, Halenda PP (1951) The Determination of Pore Volume and Area Distributions in Porous Substances. I. Computations from Nitrogen Isotherms. J Am Chem Soc 73:373-380. https://doi.org/10.1021/ja01145a126

21. Pimenta MA, Dresselhaus G, Dresselhaus MS, Cançado LG, Jorio A, Saito R (2007) Studying disorder in graphite-based systems by Raman spectroscopy, Phys Chem Chem Phys 91276-91290. 
https://doi.org/10.1039/B613962K

22. Hellinger M, Carvalho HWP, Baier S, Wang D, Kleist W, Grunwaldt JD (2015) Catalytic hydrodeoxygenation of guaiacol over platinum supported on metal oxides and zeolites. Appl Catal A Gen 490:181-192. https://doi.org/10.1016/j.apcata.2014.10.043

23. Popov A, Kondratieva E, Goupil JM, Mariey L, Bazin P, Gilson J-P, Travert A, Maugé $F$ (2010) Bio-oils Hydrodeoxygenation: Adsorption of Phenolic Molecules on Oxidic Catalyst Supports. J Phys Chem C 114:15661-15670. https://doi.org/10.1021/jp101949j

24. Rochester CH, Trebilco D-A (1978) Infrared study of the adsorption of phenols on silica immersed in heptane. J Chem Soc Faraday Trans 1 Phys Chem Condens Phases 74:1137. https://doi.org/10.1039/f19787401137

25. Rochester $\mathrm{CH}$, Trebilco D-A (1978) Infrared study of the adsorption of anisoles on silica immersed in heptane. J Chem Soc Faraday Trans 1 Phys Chem Condens Phases 74:1125. https://doi.org/10.1039/f19787401125

26. Gutierrez A, Kaila RK, Honkela ML, Slioor R, Krause AOI (2009) Hydrodeoxygenation of guaiacol on noble metal catalysts. Catal Today 147:239-246. https://doi.org/10.1016/j.cattod.2008.10.037

27. Leiva K, Martinez N, Sepulveda C, García R, Jiménez CA, Laurenti D, Vrinat M, Geantet C, Fierro JLG, Ghampson IT, Escalona N (2015) Hydrodeoxygenation of 2-methoxyphenol over different Re active phases supported on SiO2 catalysts. Appl Catal A Gen 490:71-79. https://doi.org/10.1016/j.apcata.2014.10.054

28. Olcese RN, Bettahar M, Petitjean D, Malaman B, Giovanella F, Dufour A (2012) Gas-phase hydrodeoxygenation of guaiacol over Fe/SiO2 catalyst. Appl Catal B Environ 115-116:63-73. https://doi.org/10.1016/j.apcatb.2011.12.005

29. Bui VN, Laurenti D, Afanasiev P, Geantet C (2011) Hydrodeoxygenation of guaiacol with CoMo catalysts. Part I: Promoting effect of cobalt on HDO selectivity and activity. Appl Catal B Environ 101:239-245. https://doi.org/10.1016/j.apcatb.2010.10.025

30. Ghampson IT, Sepúlveda C, Garcia R, Frederick BG, Wheeler MC, Escalona N, Desisto WJ (2012) Guaiacol transformation over unsupported molybdenum-based nitride catalysts. Appl Catal A Gen 413-414:78-84. https://doi.org/10.1016/j.apcata.2011.10.050

31. Sepúlveda C, Leiva K, García R, Radovic LR, Ghampson IT, DeSisto WJ, Fierro JLG, Escalona N (2011) Hydrodeoxygenation of 2-methoxyphenol over Mo2N catalysts supported on activated carbons. Catal Today 172:232-239. https://doi.org/10.1016/j.cattod.2011.02.061

32. Yang Y, Ochoa-Hernández C, de la Peña VA, O'Shea P, Pizarro JM, Coronado DP, Serrano (2014) Effect of metal-support interaction on the selective hydrodeoxygenation of anisole to aromatics over $\mathrm{Ni}$ based catalysts. Appl Catal B Environ 145:91-100. https://doi.org/10.1016/j.apcatb.2013.03.038

33. Robinson AM, Hensley JE, Medlin JW (2016) Bifunctional Catalysts for Upgrading of BiomassDerived Oxygenates: A Review. ACS Catal 6:5026-5043. https://doi.org/10.1021/acscatal.6b00923

34. Bui VN, Laurenti D, Afanasiev P, Geantet C (2011) Hydrodeoxygenation of guaiacol with CoMo catalysts. Part I: Promoting effect of cobalt on HDO selectivity and activity. Appl Catal B Environ 
101:239-245. https://doi.org/10.1016/j.apcatb.2010.10.025

35. Bui VN, Laurenti D, Delichère P, Geantet C (2011) Hydrodeoxygenation of guaiacol Part II: Support effect for CoMoS catalysts on HDO activity and selectivity. Appl Catal B Environ 101:246-255. https://doi.org/https://doi.org/10.1016/j.apcatb.2010.10.0311

36. Azimov F, Markova I, Stefanova V, Sharipov K (2012) Synthesis and Characterization of SBA-15 and Ti-SBA-15 Nanoprous Materials for DME Catalysts. Sharipov J Univ Chem Technol Metall 47:333340

37. Pudukudy M, Yaakob Z, Akmal ZS (2015) Direct decomposition of methane over Pd promoted Ni/SBA-15 catalysts. Appl Surf Sci 353:127-136. https://doi.org/10.1016/j.apsusc.2015.06.073

38. Shao X, Zhang X, Yu W, Wu Y, Qin Y, Sun Z, Song L (2012) Effects of surface acidities of MCM-41 modified with MoO3 on adsorptive desulfurization of gasoline. Appl Surf Sci 263:1-7. https://doi.org/10.1016/j.apsusc.2012.07.142

39. Sohn JR, Chun EW, II Paet Y (2003) Spectroscopic Studies on ZrO 2 Modified with MoO 3 and Activity for Acid Catalysis. Bull Korean Chem Soc 24:1785-1792. https://doi.org/10.5012/bkcs.2003.24.12.1785. S ) : .

40. Hojabri A, Hajakbari F, Meibodi AE (2015) Structural and optical properties of nanocrystalline a-MoO3 thin films prepared at different annealing temperatures. J Theor Appl Phys 9:67-73. https://doi.org/10.1007/s40094-014-0161-5

41. de Moura AP, de Oliveira LH, Rosa ILV, Xavier CS, Lisboa-Filho PN, Li MS, La Porta FA, Longo E, Varela JA (2015) Structural, Optical, and Magnetic Properties of NiMoO 4 Nanorods Prepared by Microwave Sintering, Sci. World J 20151-20158. https:// doi.org/10.1155/2015/315084

42. Robert DLB, Silverstein M, Francis X, Webster DJ, Kiemle, Spectrometric Identification of Organic Compounds, 8th Edition, 8th Editio, Wiley, Hoboken (2014) https://doi.org/10.1016/00222860(76)87024-X

43. Popov A, Kondratieva E, Goupil JM, Mariey L, Bazin P, Gilson J-P, Travert A, Maugé F (2010) Bio-oils Hydrodeoxygenation: Adsorption of Phenolic Molecules on Oxidic Catalyst Supports. J Phys Chem C 114:15661-15670. https://doi.org/10.1021/jp101949j

44. Ghampson IT, Sepúlveda C, Garcia R, Frederick BG, Wheeler MC, Escalona N, Desisto WJ (2012) Guaiacol transformation over unsupported molybdenum-based nitride catalysts. Appl Catal A Gen 413-414:78-84. https://doi.org/10.1016/j.apcata.2011.10.050

45. Becerra M-E, Arias N-P, Giraldo O-H, López-Suárez F-E, Illán-Gómez M-J, Bueno-López A (2012) Alumina-Supported Manganese Catalysts for Soot Combustion Prepared by Thermal Decomposition of KMnO4, Catalysts. 2: 352-367. https://doi.org/10.3390/catal2030352

46. Hosseini SA, Niaei A, Salari D (2011) Production of Y-Al2O3 from Kaolin. Open J Phys Chem 01:2327. https://doi.org/10.4236/ojpc.2011.12004

47. Salahudeen N, Ahmed AS, Al-Muhtaseb AH, Dauda M, Waziri SM, Jibril BY (2015) Synthesis of gamma alumina from Kankara kaolin using a novel technique. Appl Clay Sci 105-106:170-177. https://doi.org/10.1016/j.clay.2014.11.041 
48. Kassem M (2006) Phase relations in the Al203-MoO3 and Al-MoO3 systems, investigated by X-ray powder diffraction, FTIR, and DTA techniques, Inorg Mater. 42165-42170.

https://doi.org/10.1134/S0020168506020105

49. Ayala-G M, Puello E, Quintana PP, González-García G, Diaz C (2015) Comparison between alumina supported catalytic precursors and their application in thiophene hydrodesulfurization: (NH4)4[NiMo6024H6]·5H2O/Y-Al2O3 and NiMoOx/Y-Al2O3 conventional systems. RSC Adv 5:102652-102662. https://doi.org/10.1039/C5RA17695F

50. Tyrone Ghampson I, Sepúlveda C, Garcia R, García Fierro JL, Escalona N, DeSisto WJ (2012) Comparison of alumina- and SBA-15-supported molybdenum nitride catalysts for hydrodeoxygenation of guaiacol,Guaiacol. Appl Catal A Gen 435-436:51-60. https://doi.org/10.1016/j.apcata.2012.05.039

51. Arun N, Maley J, Chen N, Sammynaiken R, Hu Y, Dalai AK (2017) NiMo nitride supported on Y-Al 203 for hydrodeoxygenation of oleic acid: Novel characterization and activity study. Catal Today 291:153-159. https://doi.org/10.1016/j.cattod.2017.03.053

52. Kim D, Kwak BS, Park N-K, Han GB, Kang M (2015) Dynamic hydrogen production from ethanol steam-reforming reaction on Ni x Mo y /SBA-15 catalytic system. Int J Energy Res 39:279-292. https://doi.org/10.1002/er.3241

53. Kong L, Li J, Zhao Z, Liu Q, Sun Q, Liu J, Wei Y (2016) Oxidative dehydrogenation of ethane to ethylene over Mo-incorporated mesoporous SBA-16 catalysts: The effect of MoO $\mathrm{x}$ dispersion. Appl Catal A Gen 510:84-97. https://doi.org/10.1016/j.apcata.2015.11.016

54. Martins AR, Cunha IT, Oliveira AAS, Moura FCC (2017) Highly ordered spherical SBA-15 catalysts for the removal of contaminants from the oil industry. Chem Eng J 318:189-196. https://doi.org/https://doi.org/10.1016/j.cej.2016.06.053

55. Shanmugam V, Zapf R, Neuberg S, Hessel V, Kolb G (2017) Effect of ceria and zirconia promotors on $\mathrm{Ni} / \mathrm{SBA}-15$ catalysts for coking and sintering resistant steam reforming of propylene glycol in microreactors. Appl Catal B Environ 203:859-869. https://doi.org/10.1016/j.apcatb.2016.10.075

56. Kouketsu Y, Mizukami T, Mori H, Endo S, Aoya M, Hara H, Nakamura D, Wallis S (2014) A new approach to develop the Raman carbonaceous material geothermometer for low-grade metamorphism using peak width. Isl Arc 23:33-50. https://doi.org/10.1111/iar.12057

57. Gouveia Gil A, Wu Z, Chadwick D, Li K, Ni/SBA-15 (2015) Catalysts for combined steam methane reforming and water gas shift-Prepared for use in catalytic membrane reactors. Appl Catal A Gen 506:188-196. https://doi.org/10.1016/j.apcata.2015.09.009

58. Paul L, Banerjee B, Bhaumik A, Ali M (2016) Functionalized SBA-15 supported nickel (II)-oximeimine catalysts for liquid phase oxidation of olefins under solvent-free conditions. J Solid State Chem 237:105-112. https://doi.org/10.1016/j.jssc.2016.01.018

59. Occelli M, Biz S, Auroux A (1999) Effects of isomorphous substitution of Si with $\mathrm{Ti}$ and $\mathrm{Zr}$ in mesoporous silicates with the MCM-41 structure. Appl Catal A Gen 183:231-239. https://doi.org/10.1016/S0926-860X(99)00059-9 
60. Olcese R, Bettahar MM, Malaman B, Ghanbaja J, Tibavizco L, Petitjean D, Dufour A (2013) Gas-phase hydrodeoxygenation of guaiacol over iron-based catalysts. Effect of gases composition, iron load and supports (silica and activated carbon). Appl Catal B Environ 129:528-538. https://doi.org/10.1016/j.apcatb.2012.09.043

61. Luan Z, Fournier JA, Wooten JB, Miser DE, Chang MJ (2005) Functionalized mesoporous SBA-15 silica molecular sieves with mercaptopropyl groups: Preparation, characterization and application as adsorbents, Stud Surf Sci Catal, 897-906. https://doi.org/10.1016/S0167-2991(05)80302-7

62. Lee J-H, Lee E-G, Joo O-S, Jung K-D (2004) Stabilization of Ni/Al2O3 catalyst by Cu addition for CO2 reforming of methane. Appl Catal A Gen 269:1-6. https://doi.org/10.1016/j.apcata.2004.01.035

63. Kim B, Kim Y, Jae J, Watanabe C, Kim S, Jung S, Chai S, Park Y (2015) Bioresource Technology Pyrolysis and catalytic upgrading of Citrus unshiu peel. Bioresour Technol 194:312-319. https://doi.org/10.1016/j.biortech.2015.07.035

64. Omoregbe O, Danh HT, Abidin SZ, Setiabudi HD, Abdullah B, Vu KB, Vo D-VN (2016) Influence of Lanthanide Promoters on Ni/SBA-15 Catalysts for Syngas Production by Methane Dry Reforming. Procedia Eng 148:1388-1395. https://doi.org/10.1016/j.proeng.2016.06.556

65. Wu X, Jiang P, Jin F, Liu J, Zhang Y, Zhu L, Xia T, Shao K, Wang T, Li Q (2017) Production of jet fuel range biofuels by catalytic transformation of triglycerides based oils. Fuel 188:205-211. https://doi.org/10.1016/j.fuel.2016.10.030

66. Costa TMH, Gallas MR, Benvenutti EV, da Jornada JAH (1999) Study of Nanocrystalline $\gamma$-Al 203 Produced by High-Pressure Compaction. J Phys Chem B 103:4278-4284. https://doi.org/10.1021/jp9837910

67. Päivi Mäki-Arvela and Dmitry Yu. Murzin (2017) Hydrodeoxygenation of Lignin-Derived Phenols: From Fundamental Studies towards Industrial Applications, Catalysts, 7: 9 265; https://doi.org/10.3390/catal7090265

\section{Figures}



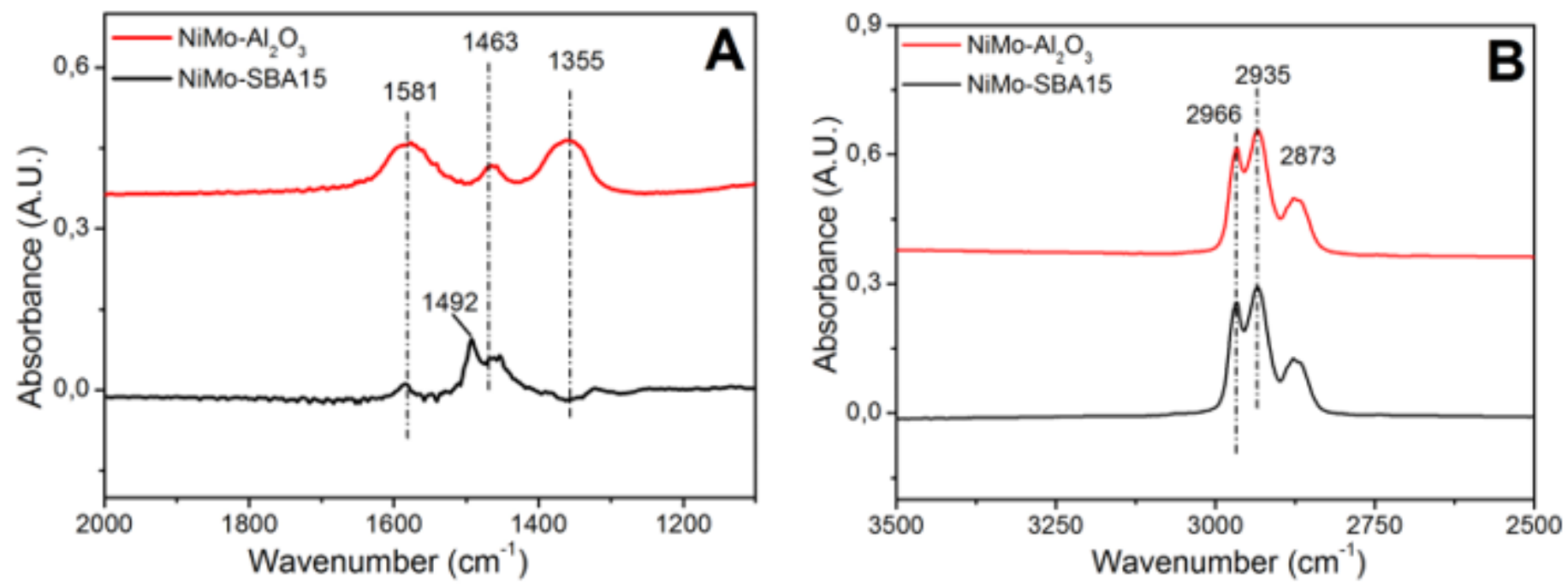

Figure 1

IR spectra of adsorbed guaiacol on NiMo-Al2O3 and NiMo-SBA15 catalysts at $200{ }^{\circ} \mathrm{C}$.
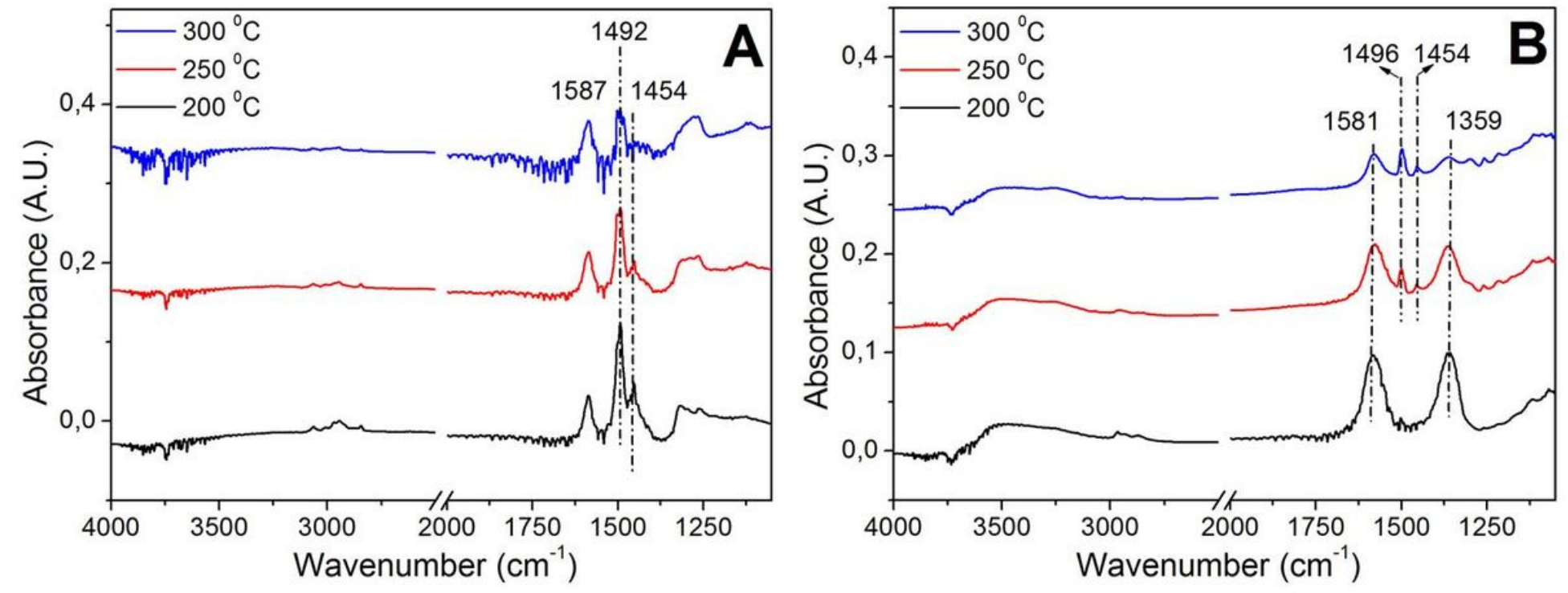

Figure 2

IR spectra of Guaiacol on NiMo-SBA15 (A) and NiMo-Al2O3 (B) catalysts after chamber evacuation at 200,250 and $300^{\circ} \mathrm{C}$. 

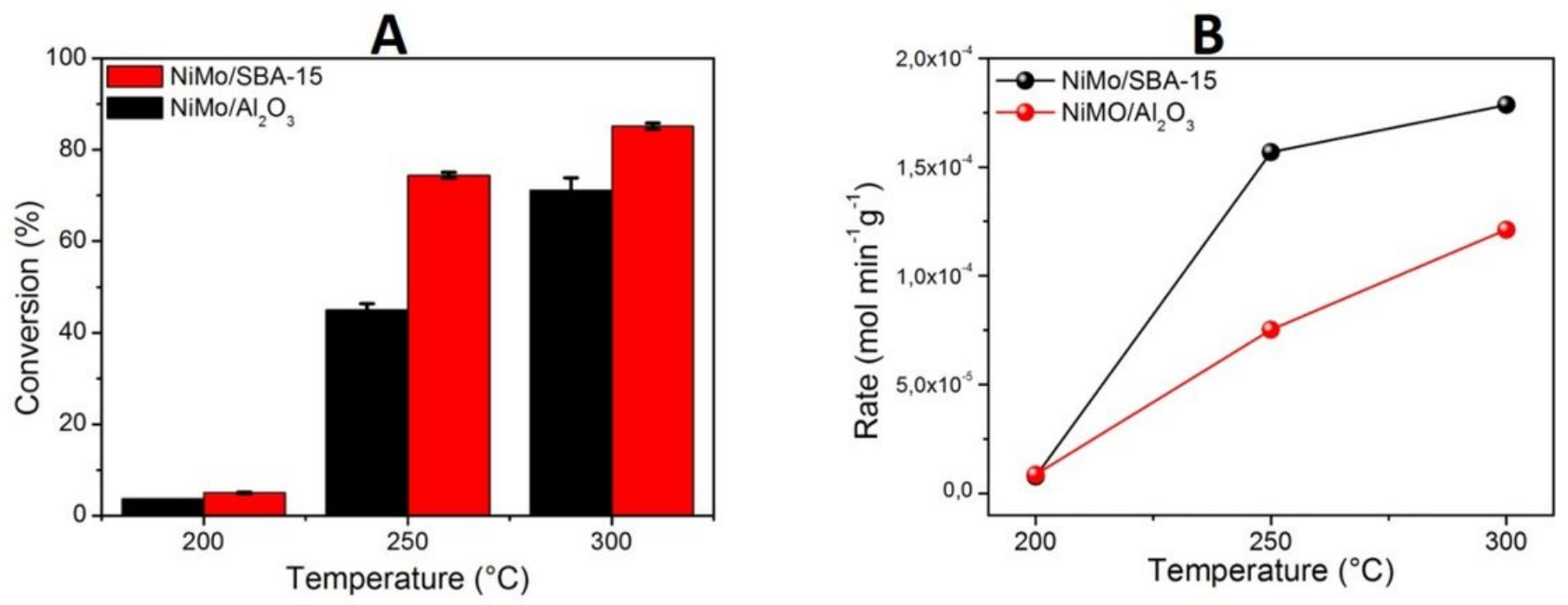

\section{Figure 3}

The support effect on the hydro deoxygenation of Guaiacol. A: Guaiacol conversion; B: Rate of the guaiacol hydro deoxygenation.
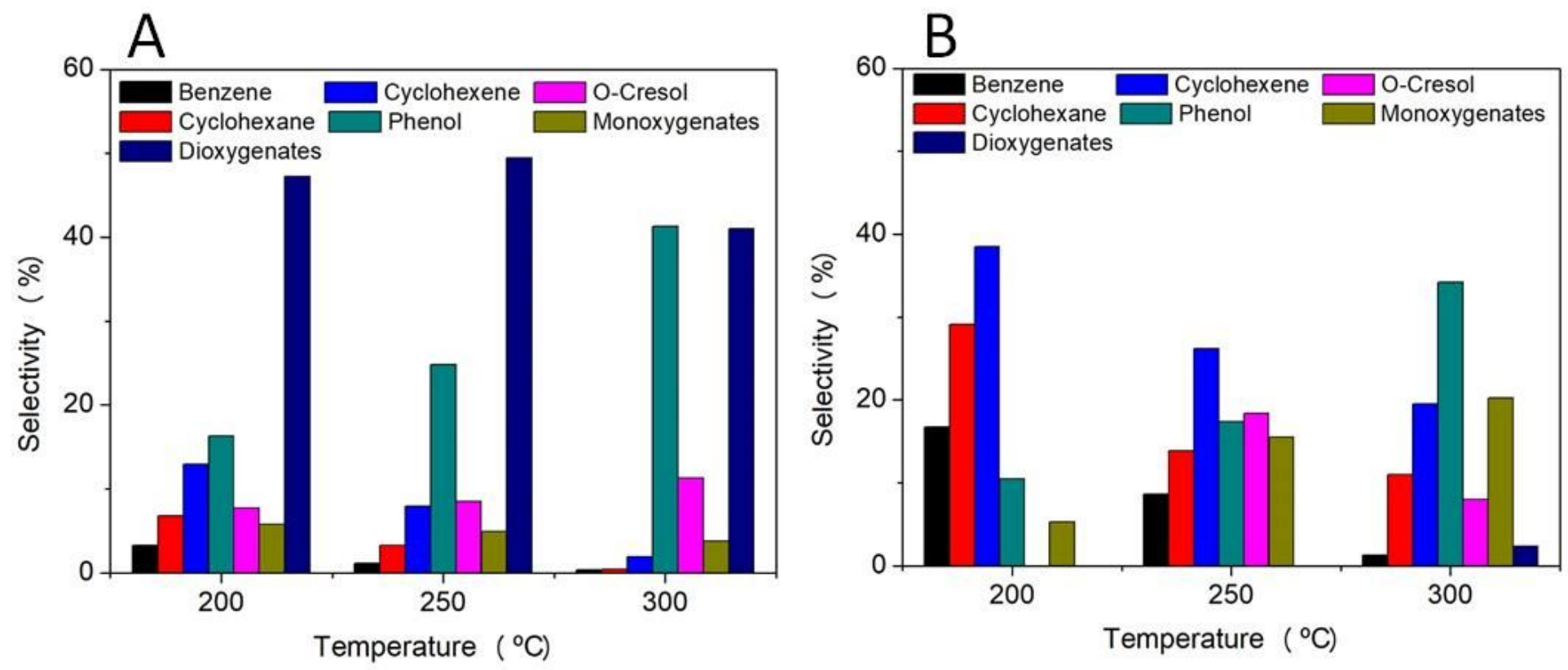

Figure 4

Selectivity and Product distribution on different catalysts 

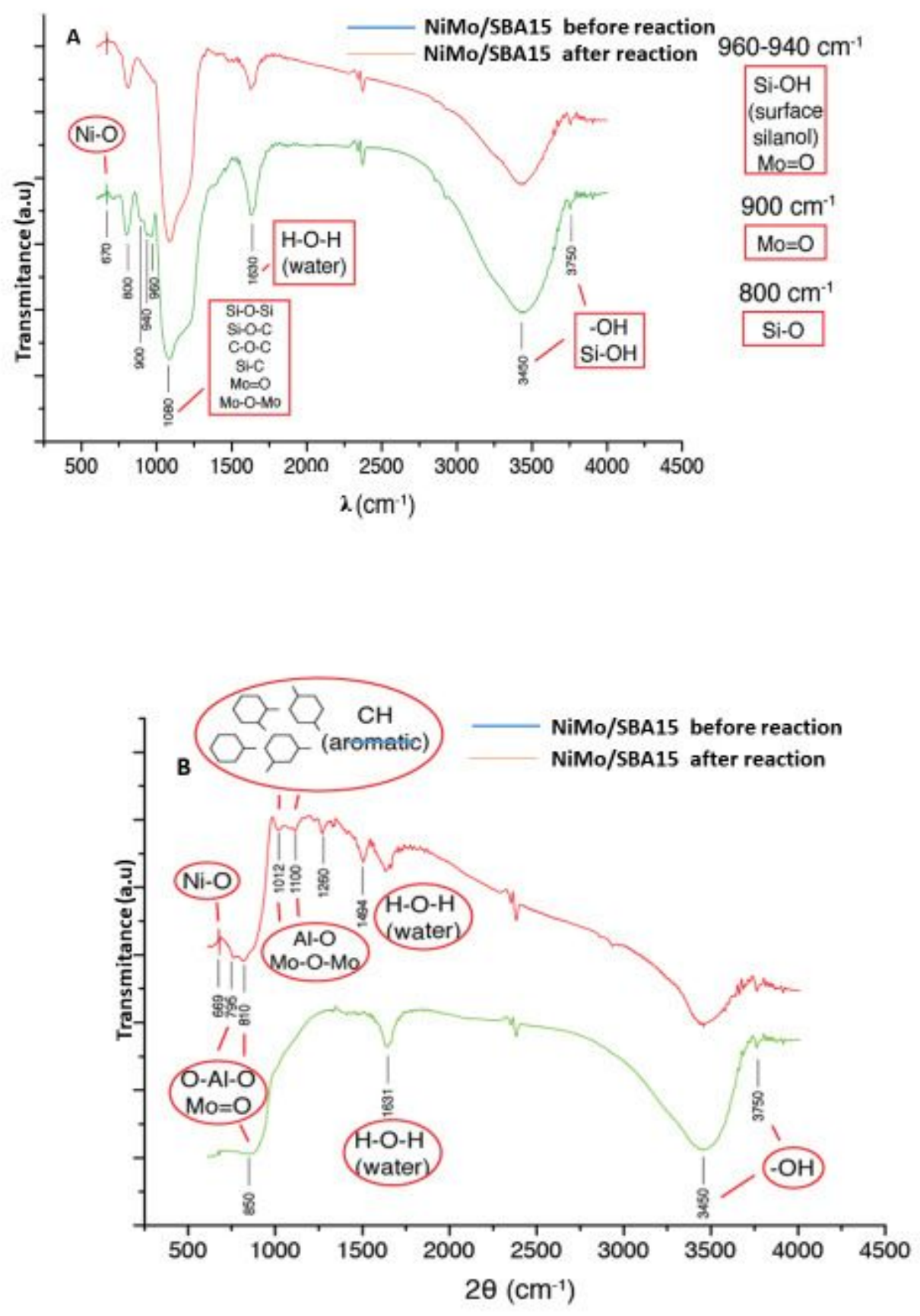

Figure 5

Infrared spectroscopy of the fresh and spent catalysts after Guaiacol hydrodeoxygenation. A:NiMo/SBA15; B: NiMo/Al2O3. 

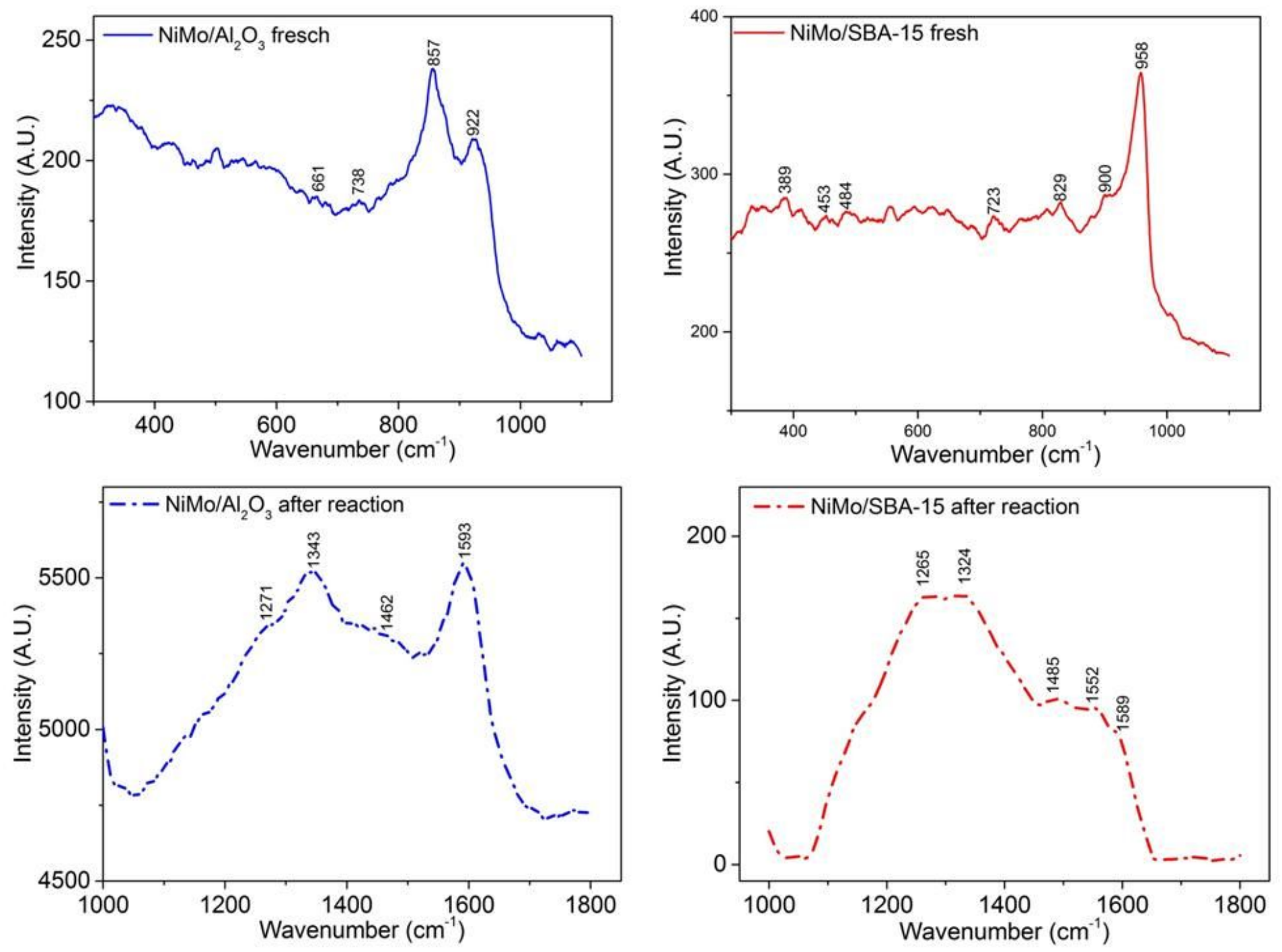

\section{Figure 6}

Raman spectrum of the catalysts NiMo/Al2O3 and NiMo/SBA-15 before and after hydro deoxygenation of guaiacol. 


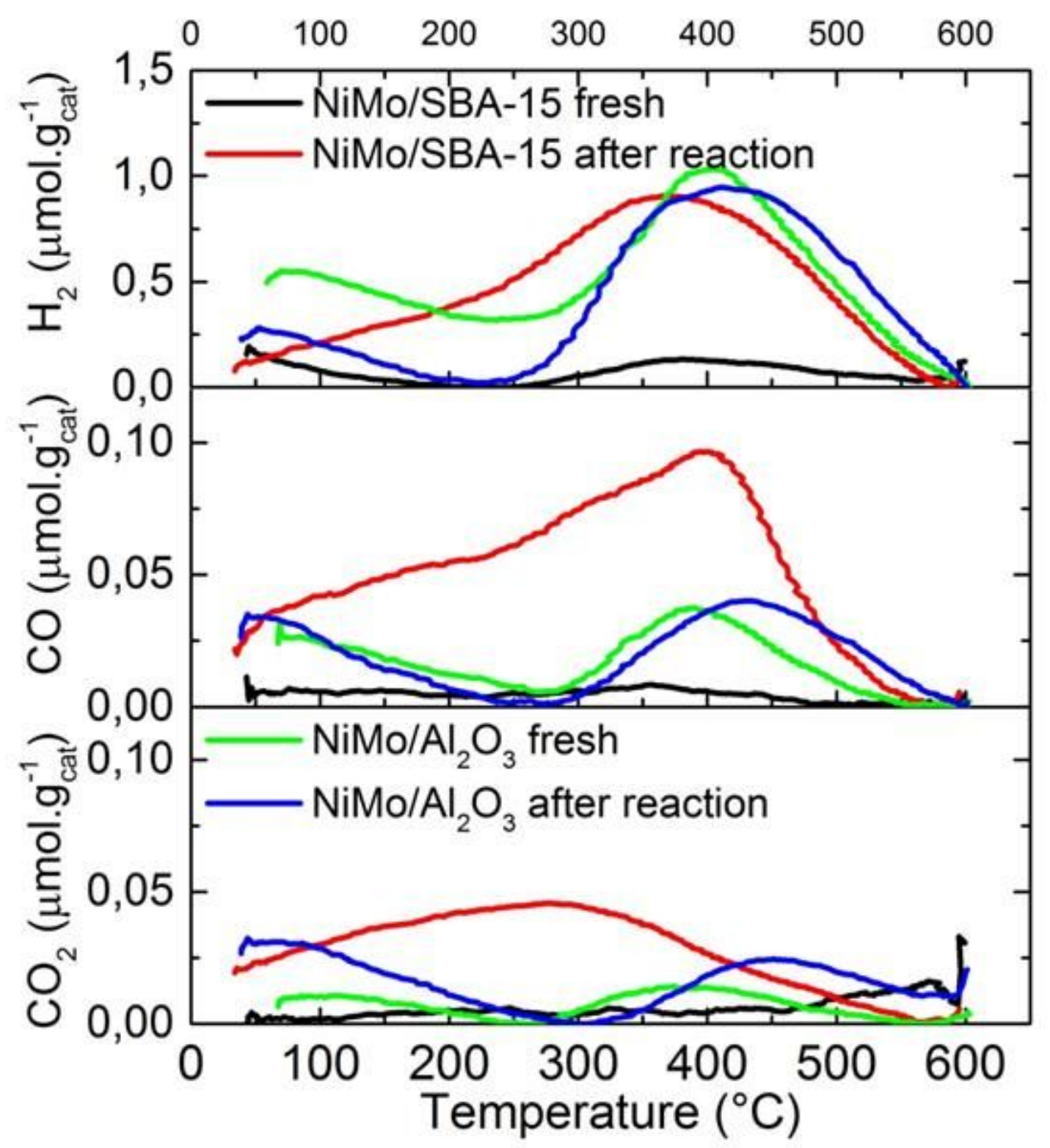

Figure 7

The Thermal programmed oxidation (TPO) analysis of catalysts until and after hydrodeoxygenation of guaiacol.

\section{Supplementary Files}

This is a list of supplementary files associated with this preprint. Click to download.

- graphicalabstract1.pptx.docx 